\title{
Characterization of Brewery Wastewater for Reuse in Kigali, Rwanda
}

\author{
Nakure Nyilimbabazi ${ }^{1}$, Noble Banadda ${ }^{2} *$, Innocent Nhapi ${ }^{1,3}$ and Umaru Garba Wali ${ }^{1}$ \\ ${ }^{1}$ WREM Project, National University of Rwanda, P.O. Box 117 Butare, Rwanda \\ ${ }^{2}$ Department of Agricultural and BioSystems Engineering, Makerere University, P.O. Box 7062, Kampala, Uganda \\ ${ }^{3}$ Department of Civil Engineering, University of Zimbabwe, Box MP169, Mt. Pleasant, Harare, Zimbabwe
}

\begin{abstract}
Like many developing countries, Rwanda is grappling with water shortages in the face of both increased urbanization and industrialization. Other options that will provide water for industrial activities without necessarily tapping into new water sources must be explored. This study investigates the prospects of wastewater re-use using a case study of Bralirwa soft drink factory (BSDF) in Kigali City, Rwanda. From August 2009 to January 2010, laboratory experiments were conducted at both Bralirwa wastewater treatment plant laboratory and National University of Rwanda water laboratory. The main objective was to characterize wastewater from BBSDF so as to determine its reuse options. The parameters analyzed included Temperature (T), Total Dissolved Solids (TDS), Total Suspended Solids (TSS), Turbidity, Ammonium Nitrogen $\left(\mathrm{NH}_{4}-\mathrm{N}\right)$, Total Nitrogen (TN), Total Phosphorus (TP), Chemical Oxygen Demand (COD), Biological Oxygen Demand (BOD 5 ), Electro-Conductivity (EC), Salinity, equivalent $\mathrm{OH}$ - and Residual Chloride. The Bralirwa soft drink factory wastewater removal efficiencies for TSS, $\mathrm{BOD}_{5}, \mathrm{EC}, \mathrm{TDS}, \mathrm{NH}_{4} \mathrm{~N}, \mathrm{TP}$, Residual Chloride, and equivalent $\mathrm{OH}-$, was $72 \% ; 93 \% ; 30 \% ; 25 \% ; 78 \% ; 30 \% ; 84 \%$ and $92 \%$, respectively. Based on recommended Rwandan wastewater quality re-use standards, this study concluded that Bralirwa wastewater re-use options are lawn irrigation, agricultural irrigation, factory reuse etc.
\end{abstract}

Keywords: Brewery wastewater, removal efficiencies, Rwanda, wastewater treatment, wastewater reuse, water quality.

\section{INTRODUCTION}

The world's supply of freshwater is limited and threatened by pollution from various human activities. Rising demands of water to supply agriculture, industry and cities are leading to competition over the allocation of the limited freshwater resources [1]. As estimated by WHO (2006), "within the next 50 years, more than $40 \%$ of the world's population will live in countries facing water stress or water scarcity". Wastewater reuse has been used in various parts of the World an alternative to address water shortages. On another front, the idea that water is an infinite resource is a reason for water shortages because its use in different sectors is with no limitations. In order to reduce water shortages, some authors, e.g. [2-6], suggest re-using treated wastewater as a reliable alternative water source. Water deficiency is the result of burgeoning population, unequal access to water resources by various social classes, growth in different sectors of the economy, practices that degrade rather than conserve water quality and the lack of institutions capable of managing water deficit and degradation [7]. In Rwanda, the direct re-use of treated wastewater is rather a new phenomenon.

*Address correspondence to this author at the Department of Agricultural and BioSystems Engineering, Makerere University, P.O. Box 7062, Kampala, Uganda; Tel: +256 77404 6689; Fax: +256-41-53.16.41;

E-mail: banadda@agric.mak.ac.ug
In 2005, it was estimated that only $54 \%$ of Rwandan population and only $44 \%$ in the rural area had access to safe water supply [8]. Considering the population increase estimated to be $40 \%$ in Kigali the capital City of Rwanda, the potential re-use of treated wastewater is worth investigation. However, it is necessary to characterize such water and determine the possible reuse applications. According to [8], performance and reliability of wastewater treatment technologies are significantly affected by variability of raw waste loadings and the nature of the treatment processes and compliance to permit limits and/or quality constraints necessary for reuse are affected by control of this variability. The re-use of treated wastewater is rather a new phenomenon in Rwanda and like in many developing countries; there are no wastewater re-use regulations. Rwanda has developed regulations for wastewater disposal [9]. The maximum allowable wastewater effluent standards for $\mathrm{pH}$ limits are $6.0-9.0,50 \mathrm{mg} \mathrm{L}^{-1}$ for total suspended solids (TSS) and Biological Oxygen Demand $\left(\mathrm{BOD}_{5}\right)$ and $250 \mathrm{mg} \mathrm{L}^{-1}$ for Chemical Oxygen Demand (COD).

Until now, water supply coverage is not sufficient in Rwanda [8] and wastewater re-use is yet to be explored. Experiences from elsewhere indicate that wastewater from soft drinks facilities could be re-used [10-14]. In 2009, the BSDF received $7,912 \mathrm{~m}^{3}$ of water and $38 \%\left(3,042 \mathrm{~m}^{3}\right)$ of the water was used to produce soft drinks whilst $48 \%\left(3,829 \mathrm{~m}^{3}\right)$ was discharged to the Bralirwa wastewater treatment plant. The prospects of re-using wastewater at Bralirwa soft drink 


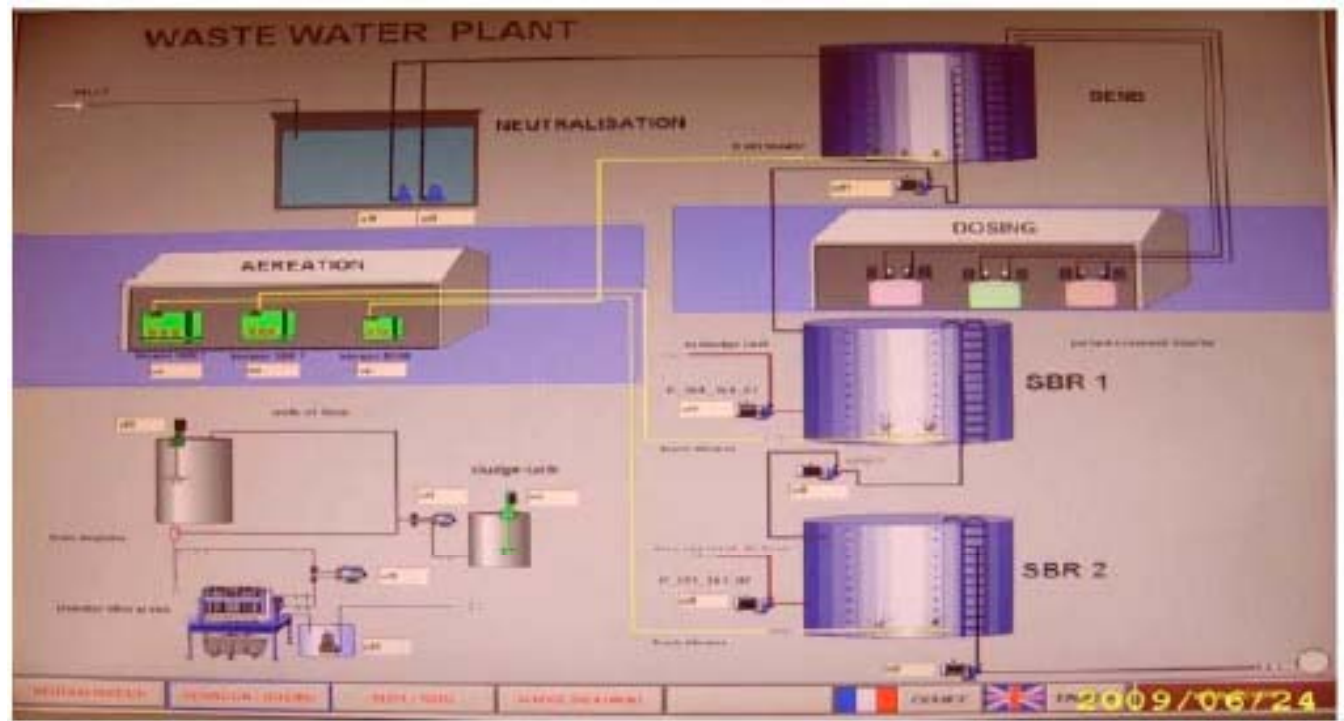

Fig. (1). A scheme of the BSDF wastewater treatment plant, Kigali, Rwanda.

factory (BSDF) therefore remain an attractive option. The main objective of this research is to characterize wastewater from BSDF and to propose possible re-use options.

\section{MATERIALS AND METHODS}

\subsection{Description of Bralirwa Soft Drink Wastewater Treatment Plant}

BSDF wastewater treatment plant in the Kicukiro District, in Kigali City (Rwanda), was officially opened in 2009. It is composed of five components as shown in Fig. (1). The Inlet tank and outlet tank have capacities of $50 \mathrm{~m}^{3}$ each. The treatment plant receives wastewater the BSDF production units only. Wastewater from the factory flows through a channel and passes through coarse screens which are intended to remove relatively large sized suspended material.

\subsection{Sample Collection and Analysis}

During this study, sampling was conducted between August 2009 and January 2010 were seasonal changes were recorded. A total of 28 samples were collected from the inlet and outlet tanks. The parameters measured at the water laboratory of the National University of Rwanda (NUR) were Total Suspended Solids (TSS), Ammonia Nitrogen $\left(\mathrm{NH}_{3}-\mathrm{N}\right)$, Total Nitrogen (TN), Total Phosphorus (TP), ElectroConductivity (EC) and equivalent OH-. Before the analysis samples were kept in the freezer in laboratory at a temperature of $0^{\circ} \mathrm{C}$. Nutrients in the wastewater were analyzed as per Standard Methods for the Examination of Water and Wastewater [15].

Other parameters namely, Physico-chemical parameters, namely Temperature (T), Total Dissolved Solids (TDS), Turbidity, Chemical Oxygen Demand (COD), Biological Oxygen Demand $\left(\mathrm{BOD}_{5}\right)$, Salinity, and Residual Chloride were measured at Bralirwa Wastewater Treatment laboratory. Portable meters $(\mathrm{HACH})$ were used to measure EC, TDS and T and DO instantaneously at point of sample collection. Turbidity was measured with a turbidity meter. The TSS was measured using the gravimetric method. The meas- urement of Most Probable Number of E.coli was performed by incubating multiple tubes in a water bath at $35^{\circ} \mathrm{C} \pm 0.5^{\circ} \mathrm{C}$ for 3 hours, and then transferred to a water bath at $44.5^{\circ} \mathrm{C} \pm$ $0.2^{\circ} \mathrm{C}$. After $21 \pm 2$ hours, tubes were examined for growth and gas production. Gas production in 24 hours or less was a positive reaction indicating the presence of fecal coliforms. The faecal coliforms were analysed because of their health impacts in wastewater re-use. The Removal Efficiency (RE) was computed based on Equation (1):

$$
R E=\frac{C_{i}-C_{f}}{C_{i}} \times 100
$$

with $C_{i}$ is value of parameter before treatment; $C_{f}$ is the value of the parameter after treatment.

\subsection{Data Analysis}

The data obtained were analyzed using descriptive statistics in Microsoft Excel. The results were expressed in terms of mean and standard deviation. The results were compared with standard water quality guidelines. A one-way analysis of variance test was used to compare the difference between means.

\section{RESULTS AND DISCUSSIONS}

\subsection{Characterization of BSDF Wastewater}

Table 1 summarizes the Removal Efficiency (RE) results of physico-chemical and microbiological parameters at the inlet and outlet at BSDF wastewater treatment plant.

With the exception of residual chlorides, Table 1 shows good removal efficiency and/or absence of faecal coliforms when pollutant concentrations in the influent and effluent were compared. According to Table $\mathbf{1}$ the wastewater treatment process best removed COD with an efficiency of $97 \%$ and least removed $\mathrm{TN}$ with an efficiency of $24 \%$. The increase in residual chloride concentration was attributed to the use of chlorides in cleaning activities in the Bralirwa Soft Drink plant. The inlet and outlet temperature of the wastewater remained more or less the same due to the hot oxygen 
Table 1. Variation of Physico-Chemical and Microbiological Parameters Considering the Inlet and Outlet Tanks at BSDF Wastewater Treatment Plant, August 2009 and January 2010

\begin{tabular}{|c|c|c|}
\hline Parameters & Influent & Effluent \\
\hline Temperature $\left({ }^{\circ} \mathrm{C}\right)$ & $29.7 \pm 2.0$ & $28.1 \pm 0.9$ \\
\hline $\mathrm{TSS}\left(\mathrm{mg} \mathrm{L}^{-1}\right)$ & $66.3 \pm 23.2$ & $24.5 \pm 17$ \\
\hline Salinity $\left(\mathrm{mg} \mathrm{L}^{-1}\right)$ & $2.6 \pm 0.4$ & $1.7 \pm 0.5$ \\
\hline $\mathrm{Ec}\left(\mu \mathrm{Scm}^{-1}\right)$ & $4,565 \pm 1,278$ & $3,393 \pm 552$ \\
\hline Nitrate $\left(\mathrm{mg} \mathrm{L}^{-1}\right)$ & $4.6 \pm 5$ & $1.0 \pm 0.8$ \\
\hline Nitrite $\left(\mathrm{mg} \mathrm{L}^{-1}\right)$ & $0.04 \pm 0.02$ & $0.01 \pm 0$ \\
\hline $\mathrm{NH}_{4}-\mathrm{N}\left(\mathrm{mg} \mathrm{L}^{-1}\right)$ & $1.30 \pm 1.1$ & $0.3 \pm 0.2$ \\
\hline $\mathrm{TN}\left(\mathrm{mg} \mathrm{L}^{-1}\right)$ & $3.0 \pm 5.5$ & $1.5 \pm 2.3$ \\
\hline $\mathrm{TP}\left(\mathrm{mg} \mathrm{L}^{-1}\right)$ & $7.0 \pm 4.0$ & $4.1 \pm 13.1$ \\
\hline Chloride $\left(\mathrm{mg} \mathrm{L}^{-1}\right)$ & $0.4 \pm 0.1$ & $0.5 \pm 0.1$ \\
\hline $\mathrm{BOD}_{5}\left(\mathrm{mg} \mathrm{L}^{-1}\right)$ & $197 \pm 25.4$ & $22.5 \pm 9$ \\
\hline $\mathrm{COD}\left(\mathrm{mg} \mathrm{L}^{-1}\right)$ & $1,757.8 \pm 951.0$ & $35.3 \pm 11.3$ \\
\hline $\mathrm{FC}(\mathrm{CFU} / 100 \mathrm{~mL}$ & No faecal coliforms & No faecal coliforms. \\
\hline
\end{tabular}

from the compressors which is supplied during the aeration step. Encouraged by these findings, the BSDF wastewater treatment plant was divided into 10 segments in order to investigate changes in pollutant concentrations. A total of 14 samples were taken and analyzed for each segment. Table $\mathbf{2}$ shows measured concentrations of different parameters at selected sampling sites.

\subsection{Temperature, $\mathbf{p H}$ and EC Profiles at BSDF Wastewater Treatment Plant}

Fig. (2) shows temperature and EC profiles across the 10 sampling sites at BSDF wastewater treatment plant.

In Fig. (2a), the highest temperature measured was 30.5 $\pm 1.6^{\circ} \mathrm{C}$ for plant influent and the lowest was $26.6 \pm 1.3{ }^{\circ} \mathrm{C}$ at site SBR2b. In general, between influent and sampling site, outlet tank, the $\mathrm{P}(\mathrm{T}<=\mathrm{t})=0.00024$, which means that the decrease in temperature was highly significant. Between Inlet1 and Inlet 2 sites, the $\mathrm{P}(\mathrm{T}<=\mathrm{t})$ was equal to 0.05 , indi- cating that the change in temperature was significant. For the other 8 sites, the $\mathrm{P}(\mathrm{T}<=\mathrm{t})$ values were greater than 0.05 , hence any change in temperature at these sites was not significant. The mean temperature recorded for the wastewater explored for re-use purposes during this study was $27.4 \pm 0.5^{\circ} \mathrm{C}$. This temperature allows the psychrophilic micro organisms to thrive because they thrive in temperature range of $-2^{\circ}$ to $30^{\circ} \mathrm{C}$, with optimality requiring $12^{\circ} \mathrm{C}$ to $18^{\circ} \mathrm{C}$. Mesophilic micro organisms also thrive in temperature of $20^{\circ} \mathrm{C}$ to $45^{\circ} \mathrm{C}$, with optimality ranging from $25^{\circ} \mathrm{C}$ to $40^{\circ} \mathrm{C}$ [16].

In Fig. (2b), the wastewater $\mathrm{pH}$ ranged between $7.5 \pm 0.3$ and 11.8 \pm 0.8 . A Statistical analysis suggested that the variation in $\mathrm{pH}$ was significant with $\mathrm{P}(\mathrm{T}<=\mathrm{t})$ of $0.02,0.00,0.04$, for influent and inlet1; inlet2 and EQ1, respectively. For the influent and outlet tank sites, the $\mathrm{P}(\mathrm{T}<=\mathrm{t})$ value of 0.000002 indicates that during treatment process, there was a significant decrease in $\mathrm{pH}$. The allowable $\mathrm{pH}$ range for wastewater discharged into the environment should vary between 6.5 and $8.5[17,18]$. This means that the effluent $\mathrm{pH}$ met the required standards in Rwanda.

In Fig. (2c), the highest and lowest EC values were $4,464.8 \pm 2,239.0 \mu \mathrm{S} \mathrm{cm}^{-1}$ and $3,123.8 \pm 758.7 \mu \mathrm{S} \mathrm{cm}^{-1}$ for influent and outlet sampling sites, respectively. Authors such as [1] proposed that the effluent should be in the range of 700 to $3,000 \mu \mathrm{S} \mathrm{cm}^{-1}$.

\subsection{TDS, TSS and Turbidity Profiles at BSDF Wastewater Treatment Plant}

Fig. (3) shows TDS, TSS and Turbidity profiles across the 10 sampling sites at BSDF wastewater treatment plant.

In Fig (3a) the highest TDS values measured was 2,236.4 $\pm 1,139.6 \mathrm{mg} \mathrm{L}^{-1}$ for influent. The removal efficiency of TDS was $21.5 \%$ with the final value of $1,671.0 \pm 413.0$ $\mathrm{mgL}^{-1}$, which can be tolerated for artificial discharge since the tolerance limit is $1,500 \mathrm{mg} \mathrm{L}^{-1}$ [18]. In Rwanda, the tolerance limit of discharged industrial wastewater is 2,000 $\mathrm{mg} \mathrm{L}^{-1}$ for total dissolved solids [9]. The difference in TDS was only significant between sites, inlet2 and EQ1, where statistically the $\mathrm{P}(\mathrm{T}<=\mathrm{t})$ value was equal to 0.034 . Differ ences in total dissolved salts with respect to the other sites were not statistically significant $(\mathrm{P}(\mathrm{T}<=\mathrm{t})>0.05$.

Table 2. Variation of Physico-Chemical Parameters Considering the Exit of the Bralirwa Soft Drink plant (Influent) and Sequential Batch Reactor 1 (EQ 2), August 2009 and January 2010

\begin{tabular}{|c|c|c|c|c|c|}
\hline Parameter Measured & Influent & Inlet1 & Inlet2 & EQ1 & EQ2 \\
\hline \hline TSS $\left(\mathrm{mg} \mathrm{L}^{-1}\right)$ & $77.3 \pm 70.2$ & $105.0 \pm 67.4$ & $121.9 \pm 56.4$ & $117.5 \pm 89.5$ & $122.0 \pm 107.2$ \\
\hline Turbidity $(\mathrm{NTU})$ & $76.9 \pm 97.2$ & $132.6 \pm 236.8$ & $83.5 \pm 99.3$ & $1.7 \pm 0.5$ & $65.9 \pm 26.2$ \\
\hline Salinity $\left(\mathrm{mg} \mathrm{L}^{-1}\right)$ & $2 \pm 0.9$ & $2.5 \pm 0.8$ & $2.7 \pm 1.2$ & $0.5 \pm 0.1$ & $1.6 \pm 0.5$ \\
\hline $\mathrm{NH}_{4}-{\mathrm{N}\left(\mathrm{m} \mathrm{L}^{-1}\right)}^{\mathrm{TN}\left(\mathrm{mg} \mathrm{L}^{-1}\right)}$ & $1.4 \pm 0.4$ & $0.6 \pm 0.1$ & $0.5 \pm 0.1$ & $3.1 \pm 2.9$ & $0.4 \pm 0.1$ \\
\hline $\mathrm{TP}\left(\mathrm{mg} \mathrm{L}^{-1}\right)$ & $16.3 \pm 7.4$ & $2.2 \pm 1.9$ & $4.4 \pm 4.1$ & $15.1 \pm 8$ & $13.5 \pm 2.4$ \\
\hline Chloride $\left(\mathrm{mg} \mathrm{L}^{-1}\right)$ & $2.3 \pm 1.8$ & $15.7 \pm 7$ & $1.7 \pm 1.3$ & $2.3 \pm 1.2$ & $1.1 \pm 0.5$ \\
\hline BOD $\left(\mathrm{mg} \mathrm{L}^{-1}\right)$ & $385.0 \pm 287.4$ & $358.3 \pm 285.1$ & $356.8 \pm 286.2$ & $301.0 \pm 246.1$ & $267.3 \pm 216.8$ \\
\hline
\end{tabular}




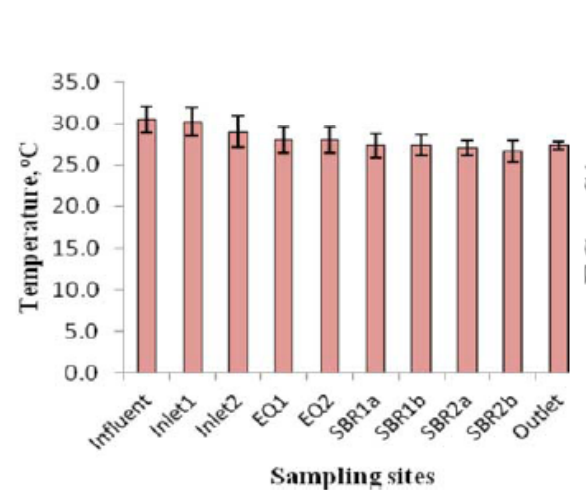

(a)

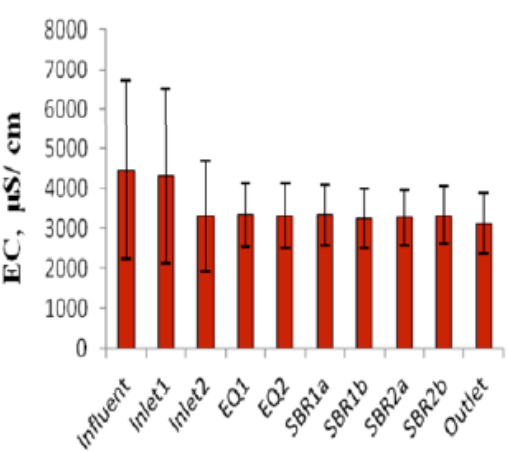

Sampling sites

(b)

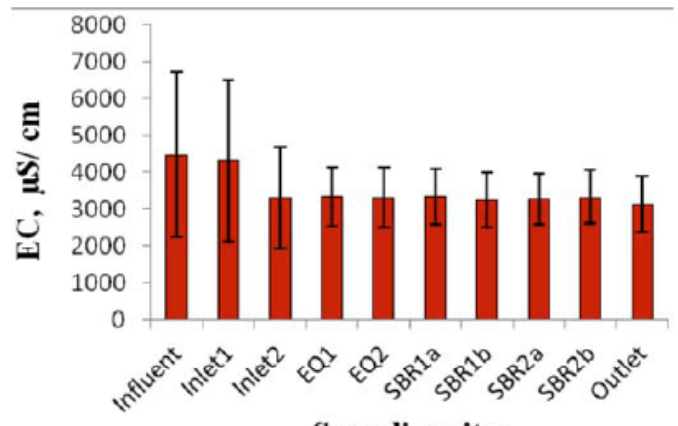

Sampling sites

(c)

Fig. (2). Profiling wastewater temperature and EC for 10 sampling sites at BSDF wastewater treatment plant, August 2009 and January 2010.

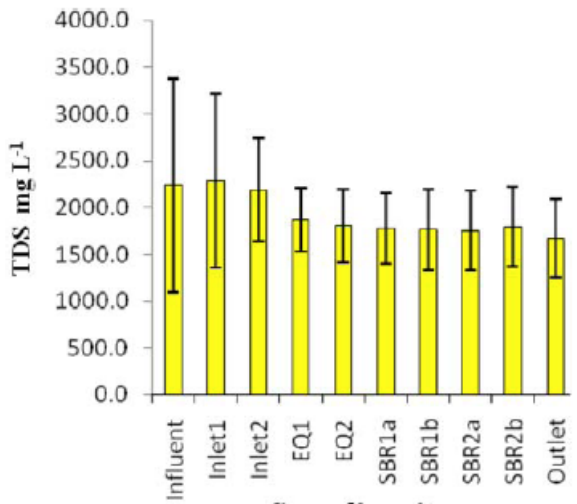

Sampling sites

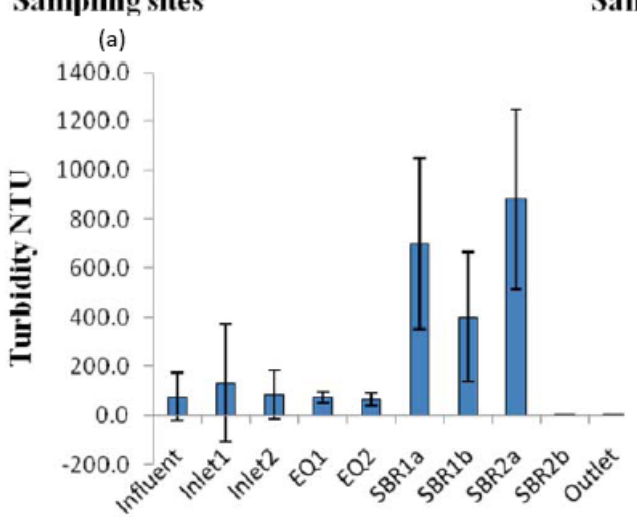

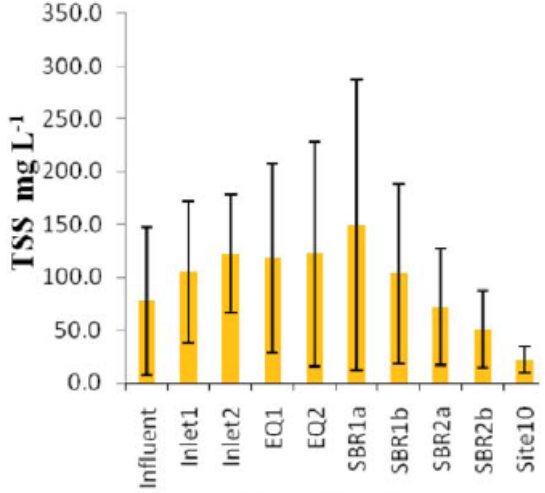

(b)

\section{Sampling sites}

(c)

Fig. (3). Profiling wastewater TDS, TSS and Turbidity for 10 sampling sites at BSDF wastewater treatment plant, August 2009 and January 2010. 


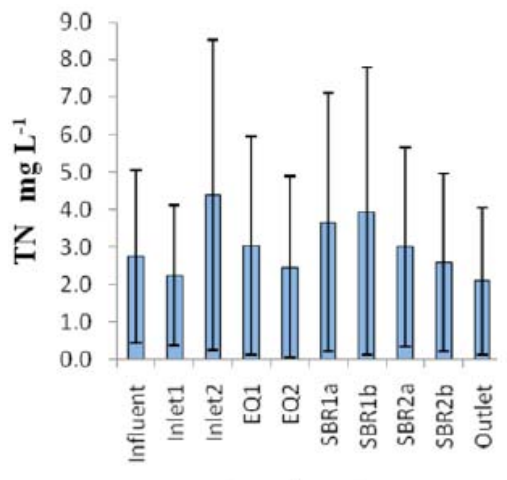

Sampling sites

(a)

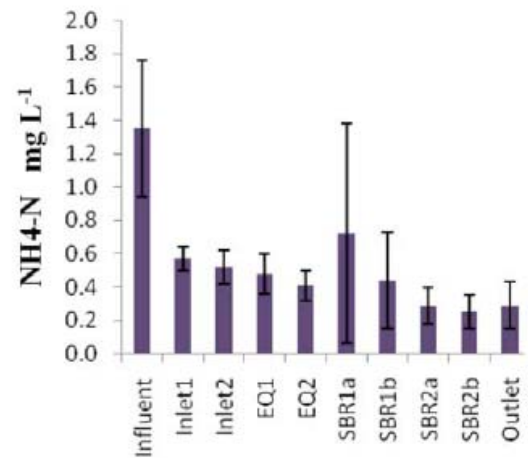

Sampling sites

(b)

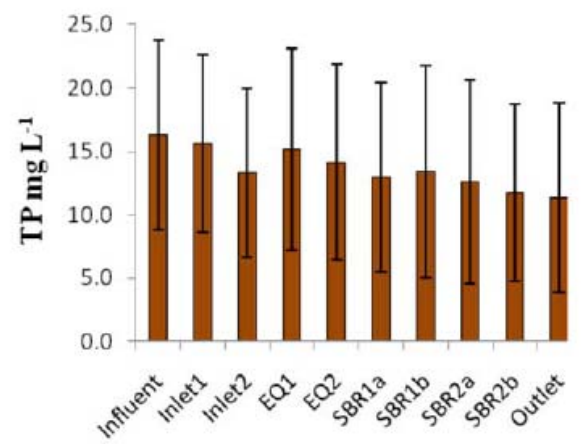

Sampling sites

(c)

Fig. (4). Profiling wastewater TN, NH4-N and TP for 10 sampling sites at BSDF wastewater treatment plant, August 2009 and January 2010.

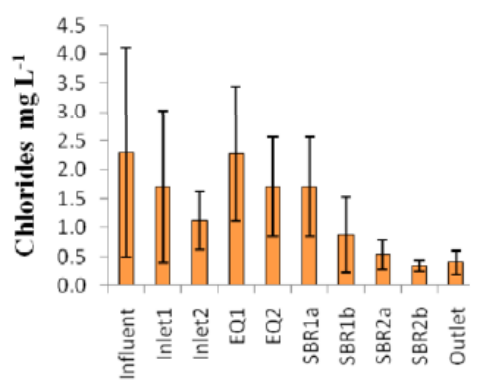

Sampling sites

(a)

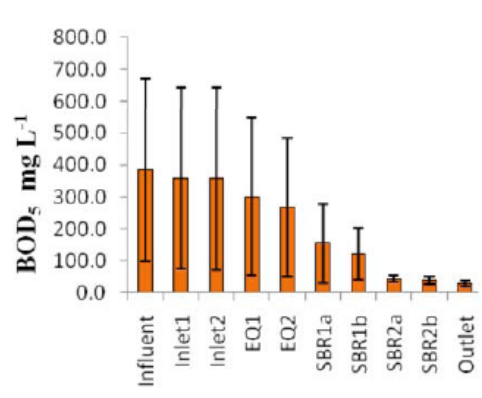

Sampling sites

(b)

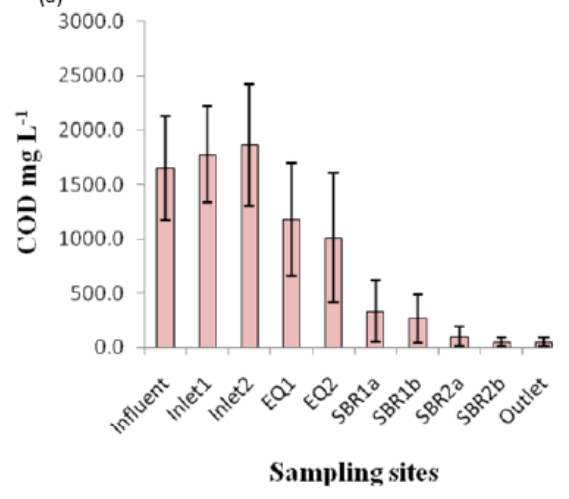

(c)

Fig. (5). Profiling wastewater Chlorides, $\mathrm{BOD}_{5}$, COD for 10 sampling sites at BSDF wastewater treatment plant, August 2009 and January 2010. 
In Fig. (3b) the highest TSS of $149.9 \pm 137.7 \mathrm{mg} \mathrm{L}^{-1}$ was measured at site, SBR1a. The difference in TSS was only significant for sampling sites SBR2a and SBR2b, where statistical value shows $P(T<=t)$ of 0.04 . All other values of $P$ $(\mathrm{T}<=\mathrm{t})$ were greater than 0.05 and the differences in TSS concentration were not significant. The overall removal efficiency of TSS was $72 \%$ with the final value of $21.7 \pm 12.6 \mathrm{mg}$ $\mathrm{L}^{-1}$. The TSS concentration suggests that the wastewater can be used in fisheries, since fisheries require reclaimed water quality of $\leq 30 \mathrm{mg} \mathrm{L}^{-1}[2,19]$. According to [20], the allowable TSS value for water reuse for irrigation is $20 \mathrm{mg} \mathrm{L}^{-1}$ hence TSS value of the wastewater from BSDF suggested the water is not suitable to be reused for irrigation. . In Rwanda, the discharge limit is $50 \mathrm{mg} \mathrm{L}^{-1}$ for total suspended solids (TSS), thus BSDF treated wastewater meets Rwanda discharge standards.

In Fig. (3c) the highest and lowest turbidity values were $879.1 \pm 366.2$ and 5.4 $\pm 0.6 \mathrm{NTU}$ at sampling sites, SBR2 and SBR2b, respectively. The turbidity tolerance limit in Rwanda for discharged wastewater is 30 NTU [9], indicating that the effluent from BSDF wastewater treatment plant meets the Rwandese standards hence can be re-used for agricultural irrigation. However, [2] reported that the allowable turbidity for this reuse is $\leq 2$ NTU.

\section{4. $\mathrm{TN}, \mathrm{NH}_{4}-\mathrm{N}$ and TP Profiles at BSDF Wastewater Treatment Plant}

Fig. (4) shows $\mathrm{TN}, \mathrm{NH}_{4}-\mathrm{N}$ and $\mathrm{TP}$ profiles across the 10 sampling sites at BSDF wastewater treatment plant.

From Fig. (4a) and (b), the highest concentration of TN and $\mathrm{NH}_{4}-\mathrm{N}$ were measured to be $4.4 \pm 4.1 \mathrm{mg} \mathrm{L}^{-1}$ and $1.5 \pm 0.4$ $\mathrm{mg} \mathrm{L}^{-1}$ respectively. These values were measured at inlet 2 for $\mathrm{TN}$ and in influent for $\mathrm{NH}_{4}-\mathrm{N}$. The $\mathrm{P}(\mathrm{T}<=\mathrm{t})$ values of $\mathrm{TN}$ suggest that there is statistically significant difference between the influent and inlet1. The difference in concentration for $\mathrm{NH}_{4}-\mathrm{N}$ was very considerable between influent and inlet1. The TN concentration usually increases in anoxic conditions and decreases in aerobic conditions, however, during this study, the removal efficiency in anoxic conditions showed negative values. This was due to the fact that in the presence of oxygen, organic nitrogen and ammonia is converted into nitrate and in the absence of oxygen, there is denitrification caused by denitrifying bacteria which strip oxygen from $\mathrm{NO}_{2-}$, and convert $\mathrm{NO}_{2}$-into $\mathrm{N}_{2}$ gas [16]. In Fig. (4c), the highest TP value is $16.3 \pm 7.4$ for the influent. The difference in TP concentration tended to increase between EQ1 and EQ2; EQ2 and SBR1a; SBR2a and SBR2b; where $\mathrm{P}(\mathrm{T}<=\mathrm{t})$ values were $0.057 ; 0.053 ; 0.056$, respectively. The mean value of TP recorded $(11.4 \pm 7.5) \mathrm{mg} \mathrm{L}^{-1}$ was obtained after an overall RE of $30 \%$ which means that the value was below that expected $\left(15 \mathrm{mg} \mathrm{L}^{-1}\right)$ for discharge into catchments areas or artificial recharge as suggested by [19-21].

\subsection{Chloride, $\mathrm{BOD}_{5}$ and COD Profiles at BSDF Waste- water Treatment Plant}

Fig. (5) shows Chloride, $\mathrm{BOD}_{5}$ and COD profiles across the 10 sampling sites at BSDF wastewater treatment plant.
In Fig. (5a), the highest chloride residual value recorded was $2.3 \pm 1.8$ for influent. The difference in chloride residual tended to be significant especially between influent and inlet1 at $\mathrm{P}(\mathrm{T}<=\mathrm{t})=0.05$. The measured chloride residual was $0.4 \pm 0.2 \mathrm{mg} \mathrm{L}^{-1}$. According to [20], the allowable effluent residual chloride should be below $1 \mathrm{mg} \mathrm{L}^{-1}$ for urban water re-use. According to [9], the minimum requirements for liquid wastes disposal and treatment for effluent residual chloride discharge is $1 \mathrm{mg} \mathrm{L}^{-1}$. Therefore the BSDF effluent meets the required standards. Fig. (5b) shows that the highest $\mathrm{BOD}_{5}$ value measured was $385.0 \pm 287.5 \mathrm{mg} \mathrm{L}^{-1}$ in the influent. There was statistical significance in the variation in $\mathrm{BOD}_{5}$ values for the influent and inlet 2 sites; SBR1b and SBR2a, SBR2b and outlet, with $\mathrm{P}(\mathrm{T}<=\mathrm{t})$ of $0.029 ; 0.024$ and 0.028 , respectively. Interestingly, the $\mathrm{P}(\mathrm{T}<=\mathrm{t})$ value of 0.01 obtained between influent and outlet sites indicates that the difference in $\mathrm{BOD}_{5}$ was significant. It can be concluded that the treatment plant removes the $\mathrm{BOD}_{5}\left(\right.$ Effluent $\mathrm{BOD}_{5}=$ $27.7 \pm 8.4 \mathrm{mg} / \mathrm{l})$. The overall $\mathrm{RE}$ for $\mathrm{BOD}_{5}$ of $92.8 \%$ was good for aerobic wastewater treatment. Aagricultural reuse for non-food crops requires $\mathrm{BOD}_{5} \leq 30 \mathrm{mg} \mathrm{L}^{-1}$, although urban reuse for parking areas, playgrounds and roadsides requires $\mathrm{BOD}_{5} \leq 10 \mathrm{mg} \mathrm{L}^{-1}[2,22]$. The maximum allowable $\mathrm{BOD}_{5}$ discharge in Rwanda is $50 \mathrm{mg} \mathrm{L}^{-1}$. As can be seen in Fig. (5c), the highest COD values measured was $1,774.0 \pm 443.4 \mathrm{mg} \mathrm{L}^{-1}$ at inlet1. Also the lowest COD measured was $50.6 \pm 38.2 \mathrm{mg} \mathrm{L}^{-1}$ at SBR2b. The $\mathrm{P}(\mathrm{T}<=\mathrm{t})$ values of $0.01,0.01,0.02$ and 0.04 suggest that there is a significant variation between influent and inlet1; EQ2 and SBR1a; SBR1b and SBR2a; SBR2a and SBR2b, respectively. RE of $70 \%$ as far as the biological treatment of soft drink wastewater was concerned [22]. The measured effluent COD of $35.3 \pm 11.26 \mathrm{mg} \mathrm{L}^{-1}$ was below allowable COD concentration for the discharge to catchments areas and surface irrigation of orchards. The allowable COD for discharge is $200 \mathrm{mg} \mathrm{L}^{-1}$ according to [18] while [1] recommended $80 \mathrm{mg} \mathrm{L}^{-1}$ for surface irrigation. Researchers such as [20, 23] proposed COD concentration value of $\leq 103 \mathrm{mg} \mathrm{L}^{-1}$ for irrigation purposes or for discharging into streams.

\section{CONCLUSIONS}

Based on the findings of this study, it was concluded that:

1. With the exception of $\mathrm{pH}$ values, all the other parameters investigated in this work are below the WHO standards for wastewater reuse. The BSDF wastewater plant effluent meet the standards for irrigation of cooked vegetables, parking areas, playgrounds and roadsides inside Kigali City, plenteous trees and green areas, roadsides outside Kigali City, etc.

2. When Rwandan standards for treated wastewater for reuse are considered, the values measured for $\mathrm{pH}$, TSS, $\mathrm{NH}_{4}-\mathrm{N}$ and COD are below the maximum allowable. Therefore treated effluent could be safely reused.

3. Based on regulations for wastewater reuse and discharge, TDS, TSS, pH, $\mathrm{NH}_{4}-\mathrm{N}$ and COD meet the standards for wastewater reuse and discharge. Also, TN, TSS, Turbidity, pH, EC, BOD, COD were below 
the maximum allowable for irrigation. Furthermore, $\mathrm{pH}$ and residual chloride recorded meet the standards for wastewater reuse for urban re-use.

4. The Bralirwa soft drink factory wastewater treatment process exhibited highest and lowest removal efficiencies for $\mathrm{COD}$ and $\mathrm{TN}$ of $97 \%$ and $24 \%$, respectively. The removal efficiencies for TSS, $\mathrm{BOD}_{5}, \mathrm{EC}$, TDS, $\mathrm{NH}_{3}-\mathrm{N}$, TP, Residual Chloride, and equivalent $\mathrm{OH}-$, were $72 \% ; 93 \% ; 30 \% ; 25 \% ; 78 \% ; 30 \% ; 84 \%$ and $92 \%$, respectively. Based recommended Rwandan wastewater quality re-uses standards, this study concluded that Bralirwa wastewater re-use options are lawn irrigation, agricultural irrigation, factory re-use etc.

5. Since water availability in Rwanda is such an important problem, known effluent purification methods should be investigated e.g., constructed wetlands, sand beds for more widespread re-use.

\section{ACKNOWLEDGEMENTS}

The authors are very grateful to Inter-University Council of Eastern Africa through Lake Victoria Research (VicRes) for accepting to pay for the publication of this work. We also thank Nuffic for sponsoring this study through the WREM Project, a collaborative capacity building project between the National University of Rwanda and the UNESCO-IHE Institute for Water Education.

\section{NOMENCLATURE}

$\begin{array}{lll}\% & = & \text { Percentage } \\ \mathrm{Mg} / 1 & = & \text { Milligram per litre }\end{array}$

\section{Acronyms}

\section{RE Removal Efficiency}

\begin{tabular}{|c|c|c|}
\hline $\mathrm{pH}$ & $=$ & potential of Hydrogen \\
\hline $\mathrm{T}$ & $=$ & Temperature \\
\hline TDS & $=$ & Total Dissolved Solids \\
\hline TSS & $=$ & Total Suspended Solids \\
\hline $\mathrm{TN}$ & $=$ & Total Nitrogen \\
\hline $\mathrm{NH}_{4}-\mathrm{N}$ & $=$ & Ammonium Nitrogen \\
\hline $\mathrm{TP}$ & $=$ & Total Phosphorus \\
\hline COD & $=$ & Chemical Oxygen Demand \\
\hline $\mathrm{BOD}_{5}$ & $=$ & Biological Oxygen Demand \\
\hline $\mathrm{EC}$ & $=$ & Electro-Conductivity \\
\hline BSDF & $=$ & Bralirwa soft drink factory \\
\hline Inlet 1 & $=$ & Inlet tank \\
\hline Inlet 2 & $=$ & Entrance to the Equalization tank \\
\hline EQ 1 & $=$ & Equalization tank \\
\hline SBR 1a & $=$ & Sequential Batch Reactor $1, \mathrm{SBR}_{1}$ \\
\hline SBR $1 b$ & $=$ & Sequential Batch Reactor $2, \mathrm{SBR}_{2}$ \\
\hline
\end{tabular}

SIDA/SAREC $=$ Swedish International Development Cooperation Agency/ Swedish International Development Cooperation Agency

VICRES = Lake Victoria Research Initiative

\section{REFERENCES}

[1] T. Manios, E. Gaki, S. Banou, D. Ntigakis, and A. Andreadakis, "Qualitative monitoring of treated wastewater reuse extensive distribution system: COD, TSS, E.C. and pH", Water SA, vol. 32, no. 1, pp. 99-104, 2005.

[2] M. Caigan, "CDC looks at links between wastewater and disease", Small flows Quarterly, vol. 6, no. 3, pp. 18 -21, 2005.

[3] M. Abu-Madi, O. Braadbart, R. Al-Sa'ed, and G. Alaerts, "Willingness of farmers to pay for reclaimed wastewater in Jordan and Tunisia", Water Science and Technology: Water Supply, vol. 3, pp. $115-22,2003$

[4] D. Mara, and S. Cairncross, "Guidelines for the Safe Use of Wastewater and Excreta in Agriculture and Aquaculture: Measures for Public Health Protection", World Health Organization, Geneva. 187,1989

[5] H.I. Shuval, "Health guidelines and standards for wastewater reuse in agriculture: historical perspectives", Water Science and Technology, vol. 23, no. 10/12, pp. 2037-2080, 1991.

[6] H.I. Shuval, A. Adin, B. Fattal, E. Rawitz, and P. Yekutiel, "Wastewater irrigation in developing countries: health effects and technical solutions", Technical Paper Number 51. World Bank, Washington DC. p. 324, 1986.

[7] A.M. Nasser, H. Paulman, O. Sela, T. Ktaitzer, H. Cikurel, A Zuckerman, A. Meir, A. Aharoni, and A. Adin, "U.V. disinfection of wastewater effluents for unrestricted Irrigation", Water Science and Technology, vol. 54, no. 3, pp. 83-89, 2006.

[8] F.A. M. Umuhoza, I. Nhapi, U.G. Wali, and N. Banadda, "Assessment of Wastewater Management Practices in Kigali City, Rwanda", The open Environment and Biological Monitoring Journal, vol. 3, pp. $21-28,2010$.

[9] RURA, "Directives on minimum requirements for liquid wastes disposal and treatment". http:www.rura.gov.rw/board_decision/17 Accessed on 19/07/2010.

[10] WHO, "Health guidelines for the use of wastewater in agriculture and aquaculture: Report of a WHO Scientific Group”, WHO Technical Report Series 778, World Health Organization, Geneva. 74 p, 1989.

[11] L. Tebai, and I. Hadjivassilis I, "Soft drinks industry wastewater treatment", Water Science and Technology, vol. 25, pp. 45-51, 1992.

[12] R. Borja, and C.J. Banks, "Semicontinuous anaerobic digestion of soft drink wastewater in immobilized cell bioreactors", Biotechnology Letters, vol. 15, pp. 767-772, 1993.

[13] J.B. Rose, "Microbial aspects of wastewater reuse for irrigation", CRC Critical Reviews in Environmental Control, vol. 16, no. 3, pp. 231-256, 1986.

[14] S.V. Kalyuzhnyi, J.V. Saucedo and J.R. Martinez, "The anaerobic treatment of soft drink wastewater in UASB and hybrid reactors", Applied Biochemistry and Biotechnology, Vol. 66, pp. 291-301, 1997.

[15] APHA/AWWA/WEF, "Standards methods for the examination of water and wastewater", 21st ed. American Public Health Association/American Water Works Association, Washington DC, 2005.

[16] R.J. Buchanan and R. W. Seabloom, "Aerobic Treatment of Wastewater and Aerobic Treatment Units", University Curriculum Development for Decentralized Wastewater Management Module, University of Washington, Seattle, WA, 2004.

[17] A.M. Robert, "Encyclopedia of Environmental Analysis and Remediation", A Wiley Encyclopedia Series in Environmental Science, John Wiley and Sons, Inc. New York, 1998.

[18] Metcalf Eddy Inc, "Wastewater Engineering, Treatment and Reuse", 4th edition, McGraw-Hill, 2004.

[19] P.G. McCornick, A. Hijazi and B. Sheikh, "From wastewater reuse to water reclamation: Progression of water reuse Standards in Jordan", Ministry of Water and Irrigation, Amman, Jordan, 42 pp, 2004 
[20] S.A. Shehata and S.A. Badr, "Planktonic algal populations as an integral part of wastewater treatment", Environment Management and Health, vol. 7, no. 1, pp. 9-14, 1996.

[21] WHO, "Reuse of effluents: methods of wastewater treatment and health safeguards: Report of a WHO Meeting of Experts", WHO Technical Report Series No. 517. World Health Organization, Geneva, 1973.
[22] C.R. Bartone, "International perspective on water resources management and wastewater reuse: appropriate technologies", Water Science and Technology, vol. 23, no. 10/12, pp. 2039-2047, 1991.

[23] S. Lavrova and B. Koumanova, "Polishing of aerobically treated wastewater in constructed wetland system", Journal of the University of Chemical Technology and Metallurgy, vol. 42, no. 2, pp. 195-200, 2007.

(C) Nyilimbabazi et al.; Licensee Bentham Open.

This is an open access article licensed under the terms of the Creative Commons Attribution Non-Commercial License (http://creativecommons.org/licenses/by-nc/3.0/g) which permits unrestricted, non-commercial use, distribution and reproduction in any medium, provided the work is properly cited. 